\title{
CALAMAGROSTIS NYINGCHIENSIS, A NEW COMBINATION FOR DEYEUXIA NYINGCHIENSIS (POACEAE: AGROSTIDINAE), AND ITS FIRST RECORD FROM YUNNAN PROVINCE, SW CHINA
}

\author{
Beata Paszko
}

\begin{abstract}
Deyeuxia nyingchiensis is here recombined as Calamagrostis nyingchiensis comb. nov. as a result of recent studies of worldwide Agrostidinae. A new record of C. nyingchiensis is reported from Shangri-la (Zhongdian) County in Yunnan Province, SW China. Previously, C. nyingchiensis was noted from eastern Xizang and southern Sichuan, SW China. It is compared with the morphologically similar species $C$. scabrescens. A map with all known geographic records of $C$. nyingchiensis is presented.
\end{abstract}

Key words: Asia, distribution, Hengduan Mts, nomenclature, taxonomy, Xizang

Beata Paszko, Department of Vascular Plant Systematics and Phytogeography, W. Szafer Institute of Botany, Polish Academy of Sciences, Lubicz 46, 31-512 Kraków, Poland; e-mail: b.paszko@botany.pl

\section{INTRODUCTION}

Deyeuxia Beauv. is closely related to Calamagrostis Adans. based on analysis of internal and external transcribed spacer regions (Saarela et al. 2010; J. M. Saarela, unpubl. data). A comprehensive taxonomic treatment of Calamagrostis (including Deyeuxia) is now being prepared for Flora of Pan-Himalaya (Paszko, unpubl. data). Recently, Paszko (2015) placed three Himalayan species originally described under Deyeuxia in Calamagrostis. Here, a grass previously known as Deyeuxia nyingchiensis is recombined as $\mathrm{Ca}$ lamagrostis nyingchiensis comb. nov.

In Yunnan Province, NW China, Calamagrostis is represented by 3 species, and Deyeuxia by 16 (Sun 2003a, b). The number of species for these two genera has been grossly underestimated in Yunnan Province. Recently, Calamagrostis gaoligongensis (Paszko) Paszko was described as new to science from Yunnan Province (Paszko \& Pendry 2013), and four species [Calamagrostis debilis Hook. f., C. filiformis Griseb., C. himalaica (Liou ex W. L. Chen, emend. Paszko) Paszko, C. yanyuanensis J. L. Yang] were reported from Yunnan Province as new records (Paszko 2012, 2015; Paszko et al. 2013; Nobis et al. 2014).
I found two duplicates (CAS, E) of one gathering (Forestry Commision, Royal Botanic Garden Edinburgh Expedition to Deqen Prefecture (1995) no. 174) incorrectly identified as Calamagrostis aff. scabrescens Griseb., collected from the north side of Xiao Xue Shan in Shangri-la (Zhongdian) County in China's northwestern Yunnan Province. A detailed examination showed that it represents $C$. nyingchiensis and is a new record for Yunnan Province.

\section{MATERIAL AND METHODS}

All revised localities of Calamagrostis nyingchiensis mentioned in the text are shown on a map (Fig. 1) produced using SimpleMappr (http://www.simplemappr. net/). Geographic coordinates are provided for each locality. If this information was not part of the original collection data, approximate coordinates are given in square brackets.

\section{TAXONOMIC TREATMENT}

Calamagrostis nyingchiensis (P. C. Kuo \& S. L. Lu) Paszko, comb. nov.

Basionym: Deyeuxia nyingchiensis P. C. Kuo \& S. L. Lu, Fl. Xizang. 5: 221. 1987. 


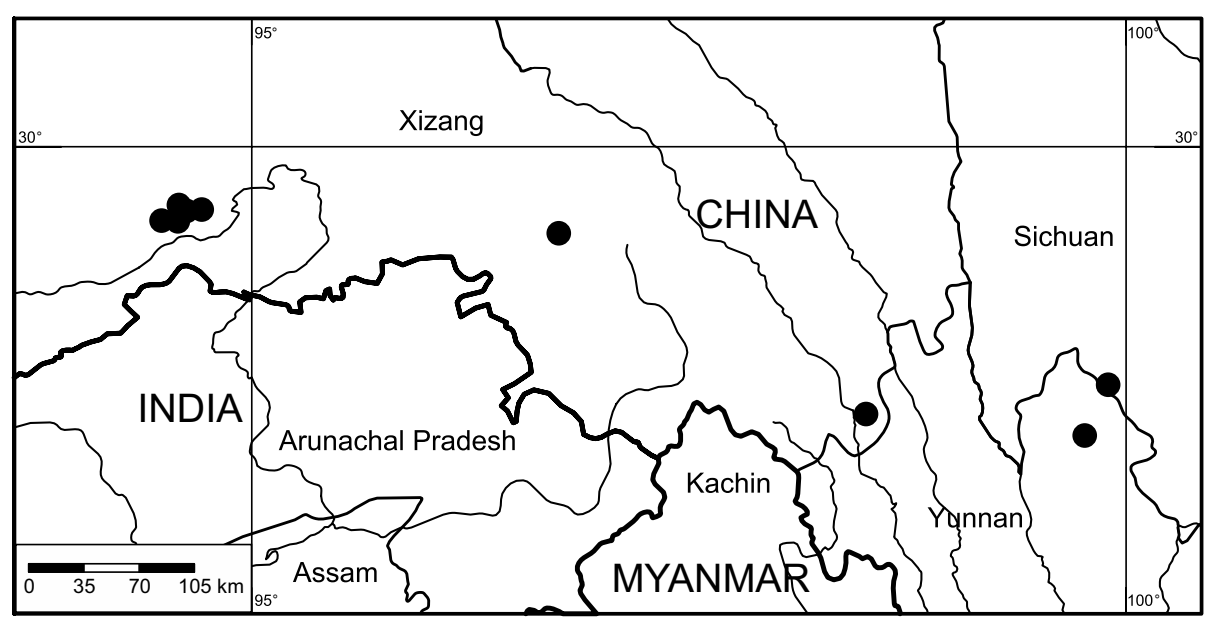

Fig. 1. Distribution map with all known geographic records of Calamagrostis nyingchiensis (P. C. Kuo \& S. L. Lu) Paszko in northwestern China (Yunnan, Sichuan and Xizang).

TyPe: CHINA. Xizang. Nyingchi xian, 30 Aug. 1977, leg. Kuo \& W.-Y. Wang 23251 (HNWP, n.v.).

Perennial, caespitose. Culms $65-100 \mathrm{~cm}$ tall, unbranched, glabrous; nodes 3-4. Sheaths ribbed, smooth, not inflated; collars smooth; ligules 3.0 $6.5 \mathrm{~mm}$ long, membranous, acute. Cauline blades 9-17 cm long, 3-6 mm wide, lanceolate-linear, gray, involute; midrib not prominent; abaxial surfaces minutely scabrous; adaxial surfaces moderately ribbed, glabrous or minutely scabrid. Panicle open, ovate in outline, 7-21 cm long; branches in whorls of 2-6, curving, spreading or ascending, the lowest panicle branches $2-8 \mathrm{~cm}$; primary branches slightly scabrous, with spikelets densely clustered in upper half of branch. Spikelets 4.6-7.4 mm long, 1-flowered; glumes subequal or equal, weakly scabrid on keel, acuminate at apex; the lower 4.6-7.4 mm long and 0.95-1.30 mm wide, 1-veined; the upper 4.3-6.9 $\mathrm{mm}$ long and 1.0-1.4 mm wide, 3-veined, 0.87-1 times as long as the lower glume; callus hairs $0.6-1.8 \mathrm{~mm}$ long, $0.22-0.47$ times as long as lemmas, surrounding the floret; lemma $2.8-3.8 \mathrm{~mm}$ long, 5-veined, $0.51-0.68$ times as long as lower glumes, apex 2-4-toothed, with dorsal awn 2.3-4.8 mm long, attached in upper half (0.48-0.82) of lemmas, not exerted from glumes or only slightly exerted; palea 1.5-2.6 mm long, 0.5-0.7 times as long as lemmas; rachilla extensions $0.8-2.0 \mathrm{~mm}$, densely bearded with hairs 3.5-5.4 mm long. Anthers 0.7-1.1 mm. Flowering in August.

TAXONOMIC NOTE. Calamagrostis nyingchiensis was described by P. C. Kuo \& S. L. Lu (in Lu \& Liou 1987: 221) based on a collection from Nyingchi County in eastern Xizang, China. Calamagrostis nyingchiensis is morphologicaly similar to C. scabrescens. Both species are characterized by a tufted habit, the presence of well-developed pennicilate rachilla prolongations in the spikelets, and the awn inserted in the upper part of the lemma back. Calamagrostis nyingchiensis differs from C. scabrescens by having shorter anthers (0.7$1.1 \mathrm{~mm}$ vs. $1.35-2.65 \mathrm{~mm}$ long), shorter lemma awns (2.3-4.8 $\mathrm{mm}$ vs. 4.75-9.25 $\mathrm{mm}$ long), and a smaller ratio of lemma to lower glume length (0.5-0.7 vs. 0.7-1.0) (Paszko, unpubl. data).

DistribUTION. Eighteen herbarium sheets of Calamagrostis nyingchiensis housed at CAS (2), E (2), HNWP (1), KRAM (1), PE (11) and US (1), representing eleven separate collection events, were located. I have not seen the type collection. Lu and Liou (1987) recorded C. nyingchiensis from Nyingchi and Yadong Counties in Xizang and also from Sichuan, China. Similar information is provided in Flora of China (Lu et al. 2006). In Xizang, C. nyingchiensis occurs in its eastern 


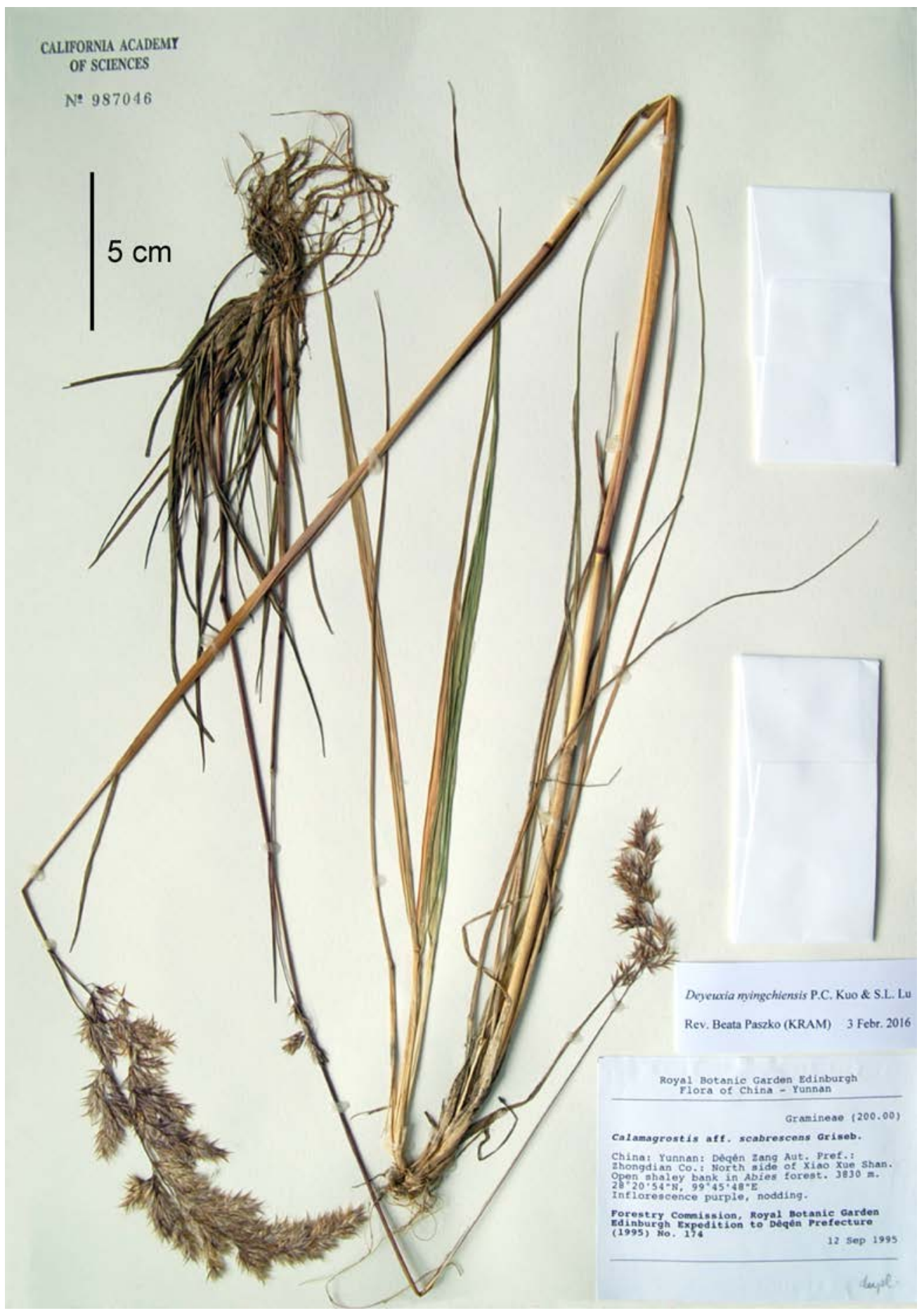

Fig. 2. Specimens of Calamagrostis nyingchiensis (P. C. Kuo \& S. L. Lu) Paszko from a newly discovered locality in Yunnan, SW China (CAS). 
part, in Baxoi, Zayü (formerly known as Tsarung) and Nyingchi Counties. In Sichuan it occurs in its southern part, in Xiangcheng County. Here I provide the first record from the northwestern Yunnan Province, where it was collected in Shangri-la (Zhongdian) County on the north side of Xiao Xue Shan at $3830 \mathrm{~m}$ a.s.1. (Fig. 2). I have not traced any specimen of $C$. nyingchiensis from Yadong County in Xizang.

Calamagrostis nyingchiensis is restricted to the Sino-Himalayan forest subkingdom ( $\mathrm{Wu}$ \& Wu 1998; Tang 2015). It has been recorded in the Hengduan Mountain region and in the East Himalayan region (the Southeast Xizang subregion). Calamagrostis himalaica (Liou ex W. L. Chen emend. Paszko) Paszko, C. debilis, and C. gaoligongensis have similar distribution limits in China (Paszko \& Pendry 2013; Paszko et al. 2013; Paszko 2014, 2015).

HaBitat. Calamagrostis nyingchiensis grows on grassy mountainsides and among alpine shrubs at 3500-4700 m a.s.1. (Lu et al. 2006). In Yunnan it was collected from an open shale bank in Abies forest at $3830 \mathrm{~m}$ a.s.l.

Specimens examined: CHINA. Sichuan. [Xiangcheng Co.], Wengsui to Xang Chen, $\mathrm{N}$ side of $\mathrm{Da}$ Xue Shan (Big Snow Mountain) pass, alt. $4100 \mathrm{~m}$, $28.6025000^{\circ} \mathrm{N}, 99.8563889^{\circ} \mathrm{E}, 7$ Oct. 1994 , leg. Alpine Garden Society Expedition to China ACE 1827 (E, CAS).

Xizang. Baxoi Co.: Ranwu to Demala Mt., alt. 4400-4600 m, [29.505 ${ }^{\circ}$, $\left.96.7556^{\circ} \mathrm{E}\right], 3$ Sept. 1983, leg. B. S. Li et al. 7362 (PE, 2 sheets). Nyingchi Co.: [without precise locality], alt. $4000 \mathrm{~m},\left[29.5774451^{\circ} \mathrm{N}\right.$, 94.4841701 ${ }^{\circ}$ E], 30 Aug. 1977, leg. B. Z. Guo \& W. Y. Wang 23292 (HNWP); Sejila Mt., S side of Serkyimla Pass, above Nyingchi (Nyingtri) and Kongpo Nyangchu (Rv) $c a 15 \mathrm{~km}$ on road to Bomi (Bome), alt. $3770 \mathrm{~m}$, $29.6666667^{\circ} \mathrm{N}, 94.5833333^{\circ} \mathrm{E}, 8$ Sept. 1997 , leg. R. J. Soreng et al. 5578 (KRAM, PE, US); Sejila Mt., alt. $3600 \mathrm{~m},\left[29.5733^{\circ} \mathrm{N}, 94.5772^{\circ} \mathrm{E}\right], 4$ Aug. 1979 , leg. T. P. Yi 79061 (PE); West slope of Sejila Mt., alt. $3500 \mathrm{~m},\left[29.5733^{\circ} \mathrm{N}, 94.5772^{\circ} \mathrm{E}\right], 2$ Aug. 1975 , leg. Qingzangbudian Team 751126 (PE, 2 sheets); East slope of Sejila Mt., alt. $4100 \mathrm{~m},\left[29.6406^{\circ} \mathrm{N}, 94.7139^{\circ} \mathrm{E}\right]$, 17 Sept. 1980, leg. Shengtaishi Gaoyuan Team 15626 (PE); Nyingchi to Sejila Mt., alt. $3900 \mathrm{~m},\left[29.6327^{\circ} \mathrm{N}\right.$, 94.6272 $\left.{ }^{\circ} \mathrm{E}\right], 19$ Sept. 1965, leg. Y. T. Zhang \& K. Y. Lang 2766 (PE). Zayü Co. [formerly known as Tsarung]:
Sacred Mt. Kar-war-kar-boo, Tsa-wa-rung, bare rocks, alt. $3500 \mathrm{~m},\left[28.4712^{\circ} \mathrm{N}, 98.5127^{\circ} \mathrm{E}\right]$, Sept. 1935 , leg. C. W. Wang 66498 (PE, 2 sheets).

YunNAN [first record]. Shangri-la (Zhongdian) Co.: $\mathrm{N}$ side of Xiao Xue Shan, alt. $3830 \mathrm{~m}, 28.3483333^{\circ} \mathrm{N}$, $99.7633333^{\circ} \mathrm{E}, 12$ Sept. 1995 , leg. Forestry Commision, Royal Botanic Garden Edinburgh Expedition to Deqen Prefecture (1995) no. 174 (E, CAS).

ACKNOwledgements. I am grateful to Miao Sun and Bing Liu (Institute of Botany, Chinese Academy of Sciences, Beijing, China) for providing the approximate geographic coordinates for Chinese collection sites and for help with reading and translating the Chinese labels into English, and to Jeffery M. Saarela (Canadian Museum of Nature, Ottawa) for helpful remarks and suggestions on the manuscript. A research visit to the herbarium at Edinburgh (E) in July 2015 was supported by the SYNTHESYS Project, financed by the European Community Research Infrastructure Action under the FP7 'Capacities' Program, grant GB-TAF-4900. This study was also financed in part from the statutory fund of the W. Szafer Institute of Botany, Polish Academy of Sciences.

\section{REFERENCES}

Lu S. L. \& Liou L. 1987. Deyeuxia Clarion. In: C. Y. WU (ed.), Flora Xizangica. 5: 213-229. Science Press, Beijing (in Chinese).

Lu S. L., Chen W. L. \& Phillips S. M. 2006. Deyeuxia Clarion ex P. Beauvois. In: Z. Y. Wu, P. H. Raven \& D. Y. Hong (eds), Flora of China-Poaceae. 22: 348-359. Science Press, Beijing \& Missouri Botanical Garden Press, St. Louis.

Nobis M., Ebel A. L., NowaK A., Turginov O. T., Kupriyanov A. N., Nobis A., Olonova M. V., Paszko B., PiwowarCzyk R., Chen W. L., Gudkova P. D., Klichowska E., NowaK S. \& Pujadas-Salvì A. J. 2014. Contribution to the flora of Asian and European countries: new national and regional vascular plant records, 2. Acta Bot. Gallica 161(2): 209-221.

PaszKo B. 2012. Taxonomic revision of Calamagrostis filiformis, C. tripilifera and their allies (Poaceae: Agrostidinae). Polish Bot. J. 57(2): 335-346.

Paszko B. 2014. Deyeuxia himalaica (Poaceae, Agrostidinae): taxonomy and its first record from Myanmar. Phytotaxa 156(5): 285-290.

PAszKo B. 2015. The first record of the Sino-Himalayan species Deyeuxia himalaica in the Yunnan Province, SW China, and three new combinations in Calamagrostis (Poaceae, Agrostidinae). Polish Bot. J. 60(2): 141-145. 
Paszko B., Chen W. L. \& Szczepaniak M. 2013. Deyeuxia debilis (Poaceae, Agrostidinae): typification, taxonomy and update of the Chinese distribution. Phytotaxa 135(1): 1-10.

Paszko B. \& Pendry C. 2013. Deyeuxia gaoligongensis (Poaceae: Agrostidinae), a new species from Gaoligong Shan in Yunnan, China. Phytotaxa 93(1): 40-46.

Saarela J. M., Liu Q., Peterson P. M., Soreng R. J. \& PaszKo B. 2010. Phylogenetics of the grass 'Aveneae-type plastid DNA clade' (Poaceae: Pooideae, Poeae) based on plastid and nuclear ribosomal DNA sequence data. In: O. Seberg, G. Petersen, A. Barfod \& J. I. Davis (eds), Diversity, phylogeny, and evolution in the monocotyledons, pp. 557-587. Aarhus University Press, Aarhus.

Sun B. 2003a. Calamagrostis Adans. In: B. Sun, D. Li \& J. XuE (eds), Flora Yunnanica. 9: 383-385. Science Press, Beijing (in Chinese).
Sun B. 2003b. Deyeuxia Beauv. In: B. Sun, D. Li \& J. Xue (eds), Flora Yunnanica. 9: 372-382. Science Press, Beijing (in Chinese).

TANG C. Q. 2015. The subtropical vegetation of southwestern China. Plant distribution, diversity and ecology. In: M. J. A. Werger (ed.), Plant and vegetation. 11: 1-363. Springer, Utrecht.

Wu C. Y. \& Wu S. G. 1998. A proposal for a new floristic kingdom (realm) - the Asiatic kingdom, its delineation and characteristics. In: A. ZHANG \& S. Wu (eds), Floristic characteristics and diversity of East Asian plants, pp. 3-42. China Higher Education Press, Beijing.

Received 9 March 2016 